\title{
Optimization of Equipment Capacity of Power Park in Volzhskiy Branch of MPEI
}

\author{
Makhsud Sultanov ${ }^{1, *}$, Elena Zenina ${ }^{1}$, Olga Zhelyaskova $^{1}$, and Dmitry Erofeev ${ }^{1}$ \\ ${ }^{1}$ National Research University «MPEI», Power Engineering Department, 404110 Volzhsky, Russia
}

\begin{abstract}
The article describes the development of an innovative microgrid landfill on the territory of the branch of NRU MPEI in Volzhskiy. The power park is considered as a microgrid with traditional and renewable energy sources. The aim of this facility is to provide heat and electricity to the institute's building and a practical study of the operation and maintenance of power equipment. The types of cogeneration plants are defined. Possible variants of the equipment layout with the determination of the power factor of each unit are considered. Trigeneration is proposed for the profitable use of the thermal steam of the units, which will contribute to saving electricity for cooling the institute in the summer. By analogy with the mathematical theory of Sharpe-Markowitz and J. R. R. Tolkien a graph of the dependence of the cost of 1 $\mathrm{kWh}$ and the risk assessment of energy supply in \% of all equipment layout options of each variant is constructed. Based on the obtained data, a conclusion is formed about the optimization of power equipment for the Power Park.
\end{abstract}

\section{Introduction}

Around the world, energy and environmental issues are becoming more acute. Every year, the number of natural resources decreases, but the population of the Earth and, therefore, the need for energy is steadily growing. Against this background, there is an increase in environmental pollution, which negatively affects the climate of the planet and the biosphere.

According to scientists, oil reserves in Russia, which has one of the largest reserves of oil and gas, based on the level of mineral production in 1991, will be enough for another 35 years, natural gas - for 81 years, coal - for 60-180 years. Therefore, world energy is looking for other types of energy resources.

At the moment, the most optimal option for replacing traditional types of energy is renewable energy sources (RES), which work from the sun, wind and water. Their main types are solar panels, small wind generators and hydroelectric power plants, wave and tidal power plants. But all RES have several drawbacks.

Firstly, the production of renewable energy greatly depends on constantly changing environmental factors, for example, the presence of sun, waves, wind, the intensity of solar radiation, the angle of incidence of rays and wind speed. Therefore, combinations of different energy sources using power storage systems are required [1].

Secondly, RES, even under ideal conditions, generate too little energy so that it can be transmitted over long distances. For example, the maximum power of solar panels in ideal conditions reaches no more than 350 Watts. Given that all types of renewable energy are extremely expensive, the transfer of such energy over long distances will be unprofitable, and the price of a kilowatt-hour for the end user will be too high. Therefore, small generation systems should be created at RES [2].

The best solution to these problems is to create a microgrid - a small energy network based on a combination of different types of RES using storage systems. This system allows independent operation of various buildings, regardless of the main power supply system's [3].

It allows us to provide energy supply to areas remote from the main power systems (for example, in Russia it is northern and central Siberia and most of the Far East) or to ensure the autonomy of buildings in case of power interruptions. An important feature of microgrid is the possibility of selling surplus electricity, which will allow it to receive a small income [4].

Microgrid can consist of several types of energy sources, both traditional and alternative, a battery substation, a voltage rectifier and a control system. The advantages of such a system are autonomy from electric and heat supply systems, higher efficiency than traditional power supply systems, obtaining small income from the sale of electricity to the grid and reducing emissions of pollutants. Microgrid can be used not only for individual buildings, but also for small areas, depending on its power [5].

Microgrid has already become widespread in Europe, Australia, the USA and Canada. They are established in houses, public places (campuses of the universities, shops, public transport, etc.), at the enterprises (the factories, the plants extracting plants) and in office

\footnotetext{
* Corresponding author: opp77@,bk.ru
} 
buildings. There are already campaigns that are engaged in the creation of microgrid (ABB, General microgrid, EDF, Enel, Engie, Iberdrola, Shell, Tokyo Electric Power Co. etc.) [6].

Currently, projects such as the Philippine microgrid have already been created or are being created (capacity of solar panels - 1.4 MW, diesel generators - 1.2 MW, volume of batteries - $2.4 \mathrm{MW} * \mathrm{~h}$ ), Pittsburgh Airport (USA) (planned to be implemented by the summer of 2021) Apple Park (US) (solar cell capacity - 17 MW, biofuel or natural gas generators - $4 \mathrm{MW}$ ), giant farms of Tesla Corporation, Indian energy projects for remote villages, Gorona Del Viento (Canary Islands) (wind farm capacity - 11.5 MW, PES - 11.32 MW, diesel generators - 11 MW), Ross Island (Antarctica) (wind farm capacity - 990 kW, diesel generators - 1125 kW)Marble Bar (Australia) (power of solar panels - $320 \mathrm{~kW}$, diesel generators - $1280 \mathrm{~kW}$ ) [7].

Microgrid construction is also planned in Russia. At the moment, a legislative framework has already been created, and international corporations have begun to create and conquer the Russian microgrid market.

At the moment Russia plans a project to provide energy supply to remote villages, sanatoriums and military facilities.

\section{Equipment layout}

Scientists of NRU MPEI in branch in Volzhskiy develop a project of a unique landfill - «Power park», which includes sources of both traditional and renewable energy. This project is the first in the Volgograd region. The facility is designed for the production of electric energy for power supply to the branch of NI MPEI in Volzhskiy, as well as for the sale of energy into a single network. To enable the implementation of scientific fundamental and applied research, the microgrid is equipped with the following systems: an APCS system, a system for collecting, storing and processing data on the operation modes and technical condition of power equipment. The innovation of the project consists in a microgeneration system consisting of a complex of installations of traditional and renewable energy sources of low capacity.

The main tasks of the landfill are:

- getting practical knowledge and skills in operation and maintenance of existing equipment for university students and teachers;

- implementation of research, design and survey works;

- switching to $100 \%$ compensation of expenses for the own needs of the branch (electric and thermal energy);

- selling energy to the market.

An important aspect is the power supply of the institute and the supply of free power to the network with respect to the reliability and quality of power supply to consumers [8].

Various types of plants up to $100 \mathrm{~kW}$ were considered: diesel generators (DGU), solar panels (SP), wind-power units (WPU), gas turbine units (GTU) and gas piston units (GPU). At the initial stage of work, 3 options for the layout of the equipment of the energy fleet were considered, which could provide the institution with electricity and heat.

The first variant of layout: GTU, GPU, SP, WPU;

The second variant of layout: SP, VGU, GPU;

The third layout option: DGU only;

The next step was to collect and process data for renewable energy sources.

After analyzing the data, the wind load and insolation graphs are shown in Figures 1-2.

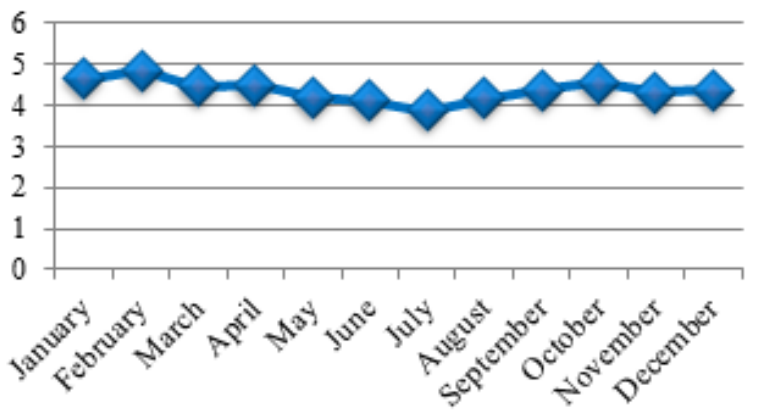

Fig. 1. Average annual wind speed, $\mathrm{m} / \mathrm{s}$ in Volgograd.

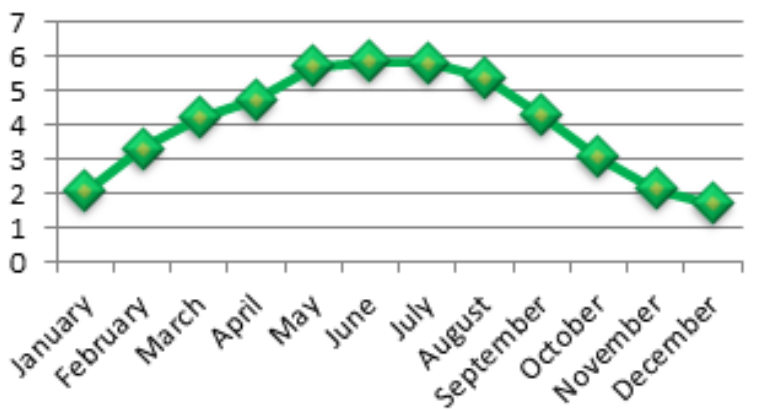

Fig. 2. Average annual insolation, $\mathrm{kWh} / \mathrm{m}^{2}$ in Volgograd.

Having reviewed several types of wind generators, electricity generation schedules had been drawing up during the year, on the basis of which it was found that the average share of energy generation from the nominal was $6.2 \%$. This indicator is very small, so the option of using WPU was rejected.

The geographically designed landfill will be located in an area with a large number of sundial hours, so the SP installation is considered in alternative layouts.

Having reviewed several types of wind generators, electricity generation schedules had been drawing up during the year, on the basis of which it was found that the average share of energy generation from the nominal was $6.2 \%$. This indicator is very small, so the option of using WPU was rejected.

The geographically designed landfill will be located in an area with a large number of sundial hours, so the SP installation is considered in alternative layouts.

Power supply option from DGU only is standby in case of emergency. Coverage of $500 \mathrm{~kW}$ of required power will be provided until the normal operation of the power park is restored. DGU operation is not provided in normal operating mode of power plant equipment. 
For further consideration, one version of equipment layout in normal operating mode remains - these are GTU, GPU and SP. The next step is to select the power for each unit.

Analysis of electricity consumption over several years has been carried out. Average values of electrical and thermal energy consumed per year are determined (Figures 3 and 4). Based on the consumption schedule, many power share distributions of each unit have been considered. 3 power distribution options have been selected to cover the energy consumed during the year. Each variant is shown in Tables 1-3. The second and third versions involve the use of part of the generated electricity for the operation of boilers to provide heat and electricity to the institute building.

Table 1. Monthly load schedules by quantity and capacity of plants used for the first capacity allocation.

\begin{tabular}{|c|c|c|c|c|c|}
\hline \multirow{2}{*}{ Months } & \multicolumn{4}{|c|}{ GPA } & \multicolumn{3}{|c|}{ GTU } & SES \\
\hline & \multicolumn{5}{|c|}{ Power, kW } \\
\hline & $\mathbf{8 0}$ & $\mathbf{2 0}$ & $\mathbf{6 5}$ & $\mathbf{3 0}$ & $\mathbf{3 8}$ \\
\hline January & 2 & 1 & 2 & 1 & 1 \\
\hline February & 2 & 1 & 2 & 1 & 1 \\
\hline March & 2 & 1 & 1 & 1 & 1 \\
\hline April & & & 1 & & 1 \\
\hline May & & & & 1 & 1 \\
\hline June & & & & 1 & 1 \\
\hline July & & 1 & & & 1 \\
\hline August & & 1 & & & 1 \\
\hline September & 1 & & & & 1 \\
\hline October & & & 1 & & 1 \\
\hline November & 1 & & 2 & & 1 \\
\hline December & 2 & 1 & 2 & & 1 \\
\hline
\end{tabular}

Table 2. Monthly load schedules by quantity and capacity of plants used for the second capacity allocation.

\begin{tabular}{|c|c|c|c|c|c|c|c|}
\hline \multirow{3}{*}{ Months } & \multicolumn{2}{|c|}{ GPA } & GTU & SES & $\begin{array}{c}\text { Gas } \\
\text { boiler }\end{array}$ & $\begin{array}{c}\text { Electric } \\
\text { boiler }\end{array}$ \\
\cline { 2 - 7 } & \multicolumn{7}{|c|}{ Power, kW } \\
\cline { 2 - 7 } & $\mathbf{7 0}$ & $\mathbf{2 0}$ & $\mathbf{6 5}$ & $\mathbf{3 8}$ & $\mathbf{2 3}$ & $\mathbf{1 4 0}$ \\
\hline January & 1 & & 2 & 1 & & 1 \\
\hline February & 1 & & 2 & 1 & & 1 \\
\hline March & & & 2 & 1 & & 1 \\
\hline April & 1 & & & 1 & & 1 \\
\hline May & & 1 & & 1 & 1 & 1 \\
\hline June & & 1 & & 1 & 1 & 1 \\
\hline July & & 1 & & 1 & & 1 \\
\hline August & & 1 & & 1 & & \\
\hline September & & 1 & & 1 & 1 & 1 \\
\hline October & 1 & & & 1 & 1 & 1 \\
\hline November & 1 & 1 & 1 & 1 & 1 & 1 \\
\hline December & 1 & & 2 & 1 & & 1 \\
\hline
\end{tabular}

Table 3. Monthly load schedules by quantity and capacity of plants used for the third capacity allocation.

\begin{tabular}{|c|c|c|c|c|c|c|}
\hline \multirow{3}{*}{ Months } & \multicolumn{2}{|c|}{ GPA } & GTU & SES & $\begin{array}{c}\text { Gas } \\
\text { boiler }\end{array}$ & $\begin{array}{c}\text { Electric } \\
\text { boiler }\end{array}$ \\
\hline & \multicolumn{6}{|c|}{ Power, kW } \\
\hline & 80 & 20 & 65 & 38 & 27 & 180 \\
\hline January & 2 & & 1 & 1 & & 1 \\
\hline February & 2 & & 1 & 1 & 1 & 1 \\
\hline March & 1 & 1 & 1 & 1 & & 1 \\
\hline April & & & 1 & 1 & & \\
\hline May & & 1 & & 1 & 1 & 1 \\
\hline June & & 1 & & 1 & 1 & 1 \\
\hline July & & 1 & & 1 & & 1 \\
\hline August & & 1 & & 1 & & \\
\hline September & & & 1 & 1 & & \\
\hline October & 1 & & & 1 & & 1 \\
\hline November & 1 & & 1 & 1 & 1 & 1 \\
\hline December & 2 & & 1 & 1 & & 1 \\
\hline
\end{tabular}

Based on the obtained data, plots of coating of electric and thermal energy are built. Figures 3 and 4 show the thermal and electrical power consumption and generation schedules for each option. The graph shows that the generated power in the first case will completely cover the load and the possible total release will be 1023 $697 \mathrm{kWh}$. With the 2nd version, a total release of 130 $000 \mathrm{kWh}$ is possible. In the case of the $3 \mathrm{rd}$ option, the total vacation will be $140000 \mathrm{kWh}$.

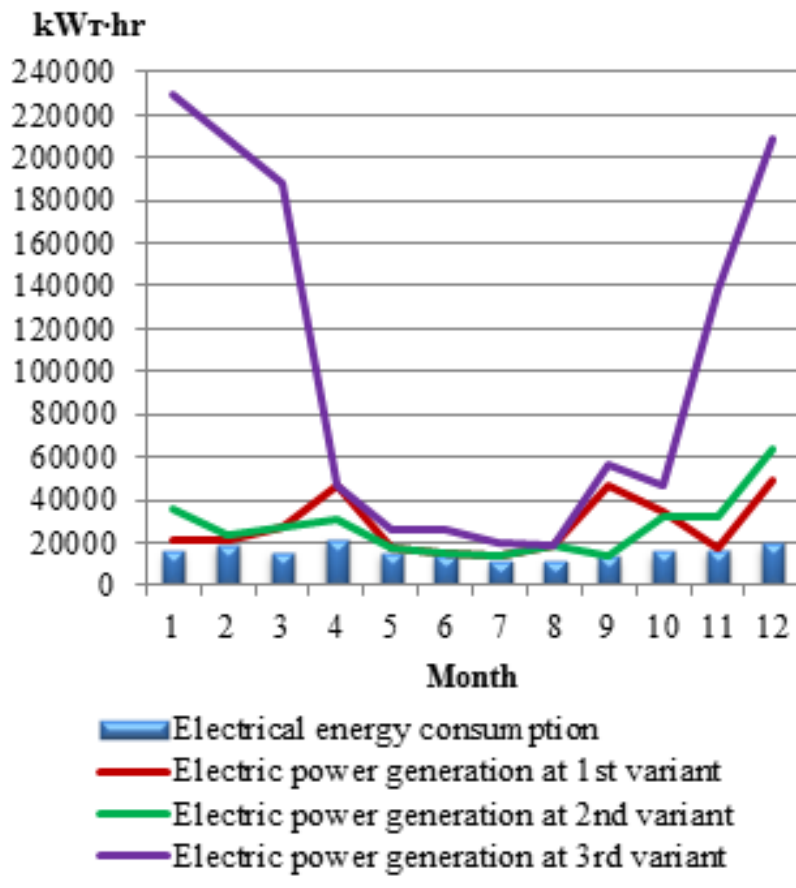

Fig. 3. Annual electric power generation. 


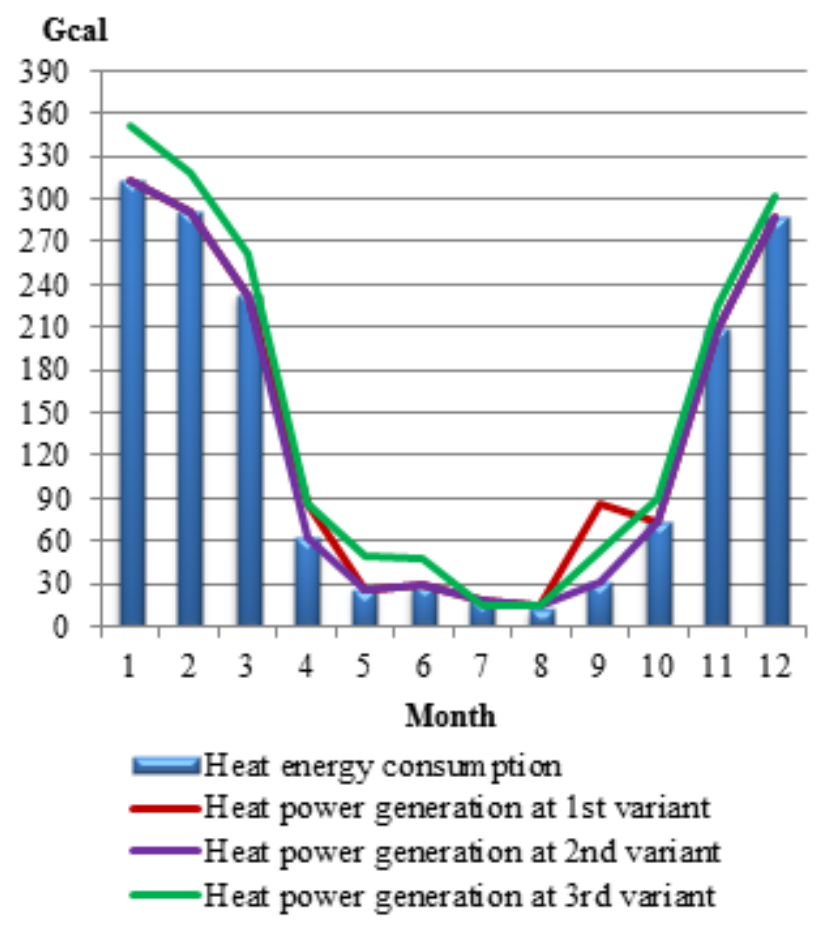

Fig. 4. Annual heat power generation.

After considering the loading options of the units, the question arises about the correctness of putting the units into reserve for a short time. The conclusion to the reserve is justified by the fact that for GPU and GTU the side effect is the generation of heat, which in some months is not necessary to consume. In this regard, the aggregate is idle, which is unprofitable $[9,10]$.

Final option is: GPU $(100 \mathrm{~kW})$, GTU $(2 \times 65 \mathrm{~kW})$, Kazovy copper $(100 \mathrm{~kW})$, Electric copper $(100 \mathrm{~kW})$, SP $(22 \mathrm{~kW})$. It was decided to constantly load all units with a total capacity of $452 \mathrm{~kW}$, sell excess electricity to the power grid. The total output of electricity to the grid will be about $3845956 \mathrm{~kW}$ per year.

Power generation and transmission

The generation of excess heat energy will be directed to the generation of cold using the trigeneration process. Such a process is used for the technological needs of the enterprise and for air conditioning of premises, as well as will contribute to the saving of electricity generation for the operation of air conditioners [11].

The load graph filling coefficients were calculated, showing how densely the electrical load graph is filled for each of the variants [12].

The following values were obtained: for 1 variant 0.156 ; for the 2 nd variant -0.588 ; for the 3 rd version 0.57 ; the final version is 0.049 .

Analysis of data showed that the last version of the equipment composition is the most profitable and costeffective.

\section{Equipment optimization}

A methodology for optimizing the parameters of microgenerating energy complexes [13] is known, the essence of which is to minimize the variance in the cost of energy generated by the microgrid per unit time. The main task of this optimization is to choose the power of the equipment with a minimum risk and a minimum cost of $1 \mathrm{kWh}$.

Let us consider the algorithm for calculating the optimal power shares of each of the energy sources using the example of power park. Previously, 3 power equipment layouts were proposed. Considering the possibility of using different power plant power options as part of the complex, we will consider

We apply an analogy with the mathematical theory of Sharp-Markovitz and J. Tobin, the work of one of the energy sources $(n+1)$ is denoted as independent of random perturbations - risk-free. Such a source is a diesel generator. The remaining $\mathrm{n}$ sources are dependent on various perturbations [14]. Table 4 shows the calculation formulas for determining microgrid parameters.

Table 4. Formulas for determining the parameters of microgeneration plants.

\begin{tabular}{|l|l|l|l|l|}
\hline № & $\begin{array}{l}\text { Type of } \\
\text { equipmen } \\
\mathrm{t}\end{array}$ & Parameter & Power formula, W & $\begin{array}{l}\text { Approxi } \\
\text { mate } \\
\text { cost } \\
\mathrm{kWh}, \\
\mathrm{RUB}\end{array}$ \\
\hline 1 & $\begin{array}{l}\text { Diesel } \\
\text { generator }\end{array}$ & $\begin{array}{l}\text { Cost of 1 } \\
l, \text { rub. }\end{array}$ & & $10-20$ \\
\hline 2 & $\begin{array}{l}\text { Wind } \\
\text { turbine }\end{array}$ & $\begin{array}{l}\text { Wind } \\
\text { speed, } \\
\text { m/s }\end{array}$ & $1 / 8 \rho \pi \eta_{\mathrm{e}} \eta_{\mathrm{m}} D^{2} C_{\mathrm{p}} V^{3}$ & $4-8$ \\
\hline 3 & $\begin{array}{l}\text { Flat solar } \\
\text { collector }\end{array}$ & $\begin{array}{l}\text { Insolation } \\
\text { W/m }\end{array}$ & $J \cdot S \cdot \eta$ & $5-7$ \\
\hline 4 & $\begin{array}{l}\text { Gas } \\
\text { piston } \\
\text { plant }\end{array}$ & $\begin{array}{l}\text { Cost of 1 } \\
\text { cubic } \\
\text { meter, } \\
\text { rub. }\end{array}$ & 100000 & $30-40$ \\
\hline 5 & $\begin{array}{l}\text { Combine } \\
\text { d cycle } \\
\text { plant }\end{array}$ & $\begin{array}{l}\text { Cost of 1 } \\
\text { cubic } \\
\text { meter, } \\
\text { rub. }\end{array}$ & 100000 & $30-40$ \\
\hline
\end{tabular}

After analyzing the possible arrangements and shares of capacity of each equipment, a graph of the comparative efficiency of the optimal design microgeneration plants is drawn up (Fig. 5) [15].

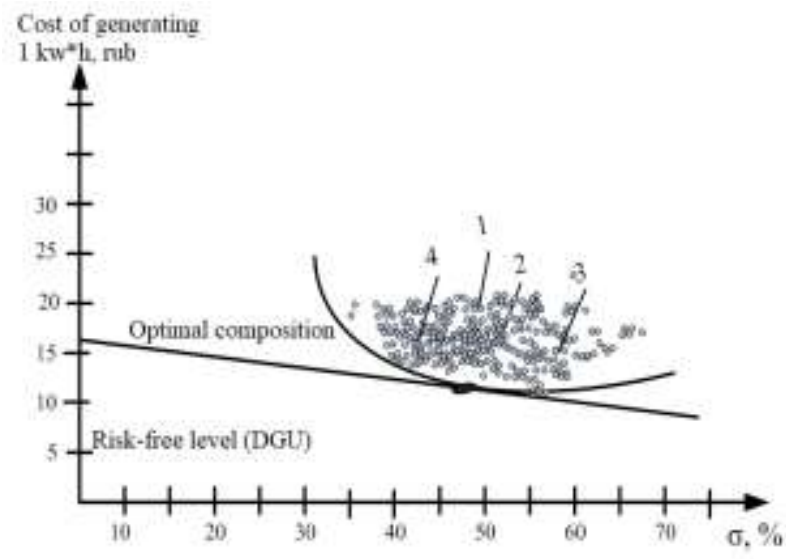

Fig. 5. Graph of comparative efficiency of optimal design microgeneration plants. 
Based on the graph obtained, it can be concluded that none of the options is optimal. The most approximate with lower risks and average cost of $1 \mathrm{kWh}$ production is the final (Figure 4) version of equipment layout. In this case, the investment yield of the landfill under consideration will be about $25 \%$.

\section{Conclusions}

In the course of the study, various equipment layouts of the Energy Park were considered, schedules of power and heat load were determined, a graph of the cost ratio of $1 \mathrm{kWh}$ and a risk assessment of energy supply (\%) was formed. The results of the study showed that according to the method of optimizing the equipment and the obtained filling factors of the load schedules of electric energy and heat, the variant of equipment layout consisting of SP, CVGU, GPU, electric and gas boilers + DGU (in case of an accident) is the most suitable.

The development of microgrids is gaining more and more turnover. In the coming years, most of the infrastructure will be provided by individual microgeneration plants. Therefore, the development of power park, as an illustrative example for the training of future energy engineers, is a priority of our institute.

The research is funded by Russian Federation public contract № FSWF-2020-0025 "Technique development and method analysis for ensuring power system object security and competitiveness based on the digital technologies"

\section{References}

1. M. Shiler, E. Rublevsky, MicroGrid - response to new challenges of the electric power industry, Control Engineering (Russia), 4 (70), 80-84 (2017)

2. O.I. Zhelyaskova, A.A. Smirnov, M.M. Sultanov, Study of work efficiency of the energy system at the introduction of small hydropower plants, The II "International Theoretical and Practical Conference on Alternative and Smart Energy" (TPCASE 2020), Voronezh, Russia, 16th-18th September 2020, Conf. Ser.: Mater. Sci. Eng., 1035 (2021)

3. MicroGrid - the future of power grids, Cases, perspectives, opportunities [Electronic resource] Available at: http://smartenergysummit.ru /novosti/microgrid-\%E2\%80\%93-budushheeelektrosetej.-kejsyi,-perspektivyi,-vozmozhnosti

4. N.G. Privalov, On a possible catastrophe in 20302050-Kh, The Age of Globalization, 63-69 (2009)

5. V.N. Kuryanov, M.M. Sultanov, E.V. Kuryanova, E.M. Scopova, Mathematical model of the processes of restoration of power equipment in power systems by criterion of the index of technical condition, The third conference «Problems of thermal physics and power engineering», Journal of physics: conference series, 1683, 1-10 (2020)
6. Distributed energy, Global investment in mininetworks could reach $\$ 128$ billion by 2030 [Electronic resource] Available at: https://energy.hse.ru/distributed

7. ABB Sustainable Development Strategy 2030 [Electronic resource] Available at: https://new.abb.com/ru/sustainability 2030

8. D.S. Alexandrov, E.F. Shcherbakov, Reliability and quality of power supply of enterprises: textbook (Ulyanovsk: U1STU, 155, 2010)

9. I.A. Boldyrev, M.M. Sultanov, N.V. Kharitonov, A.A. Beokash, P.D. Menshikov, Approaches to improving the efficiency and safety of the TPP gas economy based on internet of things technologies, The third conference «Problems of thermal physics and power engineering», Journal of physics: conference series, 1683, 1-5 (2020)

10. I.A. Boldyrev, M.M. Sultanov, N.V. Kharitonov, A.A. Beokash, P.D. Menshikov, Approaches to improving the efficiency and safety of the TPP gas economy based on internet of things technologies, The third conference «Problems of thermal physics and power engineering», Journal of physics: conference series, 1683, 1-5 (2020)

11. T.V. Pantsyrnaya, V.A. Parabin, A.V. Dyakov, Trigeneration as a way of energy efficiency improvement review article, Strategic decisions and risk management, 6, 82-87 (2013) (in Russian)

12. T.A. Shestopalova, M.M. Sultanov, O.I. Zhelyaskova, Modelling of developing capacity of power systems based on hybrid power complexes by reliability indicators, The third conference «Problems of thermal physics and power engineering», Journal of physics: conference series, 1683, 1-8 (2020)

13. V.I. Velkin, Methodology for optimizing the parameters of microgenerating energy complexes based on renewable energy sources: autoref. dis.... Dr. Technical Sciences: 05.14.08/7, St. Petersburg, 39 (2018)

14. S.P. Sidorov, E.A. Akharova, A.A. Khomchenko, N.P. Grishin, Models of optimal portfolio investment: educational method. manual for students of the Faculty of Mechanics and Mathematics (Saratov: Publishing house Sarat. un-ta, 77, 2015)

15. E.K. Arakelyan, I.A. Boldyrev, K.V. Evseev, M.M. Sultanov, V.A. Yurov, The technique for increase of generating system technical and economic indexes evaluation accuracy using machine learning, The third conference «Problems of thermal physics and power engineering», Journal of physics: conference series, 1683, 1-4 (2020). 